ҚАЗАҚСТАН РЕСПУБЛИКАСЫ

ҰЛТТЫҚ ҒЫЛЫМ АКАДЕМИЯСЫНЫҢ

Абай атындағы Қазақ ұлттық педагогикалық университетінің
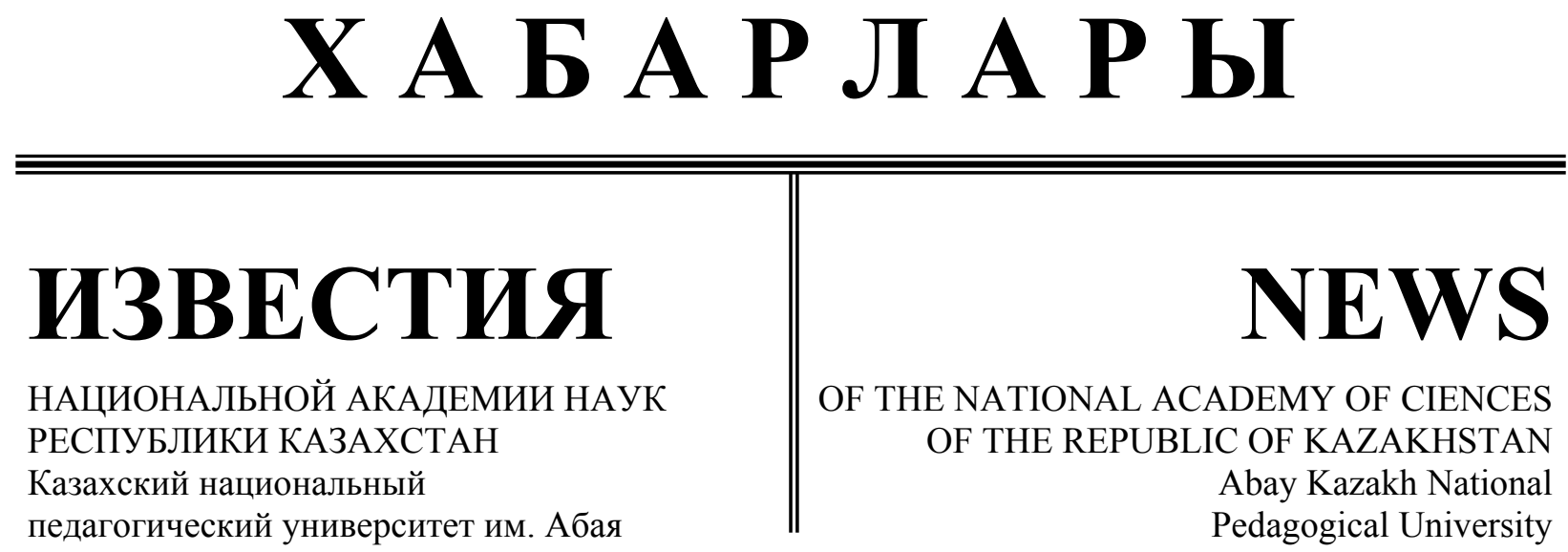

\author{
SERIES \\ OF SOCIAL AND HUMAN SCIENCES
}

2 (330)

MARCH - APRIL 2020

PUBLISHED SINCE JANUARY 1962

PUBLISHED 6 TIMES A YEAR 
Бас редактор

ҚР ҰҒА құрметті мүшесі

Балықбаев Т.O.

Р ед акция а лқ а сы:

экон. ғ. докторы, проф., ҚР ҰҒА академигі Баймұратов У.Б.; филос. ғ.докторы, проф., ҚР ҰҒА академигі Есім Г.Е.; фил. ғ. докторы,, проф., ҚР ҰҒА академигі Қирабаев С.С.; эк. ғ. докторы, проф., ҚР ҰҒА академигі Қошанов А.К.; эк.ғ. докторы, проф., ҚР ҰҒА академигі Нәрібаев К.Н. (бас редактордың орынбасары); филос. ғ.докторы, проф., ҚР ҰҒА академигі Нысанбаев А.Н.; заң ғ. докторы, проф., ҚР ҰҒА академигі Сәбікенов С.Н.; заң ғ. докторы, проф., ҚР ҰҒА академигі Сүлейменов М.К.; эк. ғ. докторы, проф., ҚР ҰҒА академигі Сатыбалдин С.С.; тарих ғ. докторы, проф., ҚР ҰҒА академик Әбжанов Х.М.; тарих ғ. докторы, проф., ҚР ҰҒА корр. мүшесі Әбусеитова М.Х.; тарих ғ. докторы, проф., ҚР ҰҒА академик Байтанаев Б.А.; филол. Ғ. докторы, проф., ҚР ҰҒА корр. мүшесі Жақып Б.А.; фил. ғ. докторы, проф., академик НАН РК Қалижанов У.К.; филол. ғ. докторы, проф., ҚР ҰҒА академик Қамзабекұлы Д.; тарих ғ. докторы, проф., ҚР ҰҒА академик Қожамжарова Д.П.; тарих ғ. док-торы, проф., ҚР ҰҒА академик Қойгелдиев М.К.; фил. ғ. докторы, проф., ҚР ҰҒА корр. мүшесі Құрманбайұлы Ш.; тарих ғ. докторы, проф., ҚР ҰҒА корр. мүшесі Таймағанбетов Ж.К.; социол. ғ. докторы, проф., ҚР ҰҒА корр. мүшесі Шәукенова 3.К.; фил. ғ. докторы, проф., ҚР ҰҒА корр. мүшесі Дербісәлі А.; саяси. ғ. докторы, проф., Бижанов А.К., тарих ғ. докторы, проф., Кабульдинов 3.Е.; фил. ғ. докторы, проф., ҚР ҰҒА корр мүшесі Қажыбек Е.3.

Р еда ц ия ке н е с і:

Молдова Республикасының ҰҒА академигі Белостечник Г. (Молдова); Әзірбайжан ҰҒА академигі Велиханлы Н. (Азербайджан); Тәжікстан ҰҒА академигі Назаров Т.Н. (Тәжікстан); Молдова Республикасының ҰҒА академигі Рошка А. (Молдова); Молдова Республикасының ҰҒА академигі Руснак Г. (Молдова); Әзірбайжан ҰҒА корр. мүшесі Мурадов Ш. (Әзірбайжан); Әзірбайжан ҰҒА корр. мүшесі Сафарова 3. (Әзірбайжан); э. ғ. д., проф. Василенко В.Н. (Украина); заң ғ. докт., проф. Устименко В.А. (Украина)

«Қазақстан Республикасы Ұлттық ғылым академиясының Хабарлары. Қоғамдық және гуманитарлық ғылымдар сериясы».

ISSN 2224-5294

Меншіктенуші: «Қазақстан Республикасының Ұлттық ғылым академиясы» РҚБ (Алматы қ.)

Қазақстан республикасының Мәдениет пен ақпарат министрлігінің Ақпарат және мұрағат комитетінде 30.04.2010 ж. берілген № 10894-Ж мерзімдік басылым тіркеуіне қойылу туралы куәлік

Мерзімділігі: жылына 6 рет.

Тиражы: 500 дана.

Редакцияның мекенжайы: 050010, Алматы қ., Шевченко көш., 28; 219, 220 бөл.; тел.: 272-13-19, 272-13-18 http://soc-human.kz/index.php/en/arhiv

(C) Қазақстан Республикасының Ұлттық ғылым академиясы, 2020

Типографияның мекенжайы: «NurNaz GRACE», Алматы қ., Рысқұлов көш., 103. 
Главный редактор

Почетный член НАН РК

T.O. Балыкбаев

Р едакционнная коллегия:

докт. экон. Н., проф., академик НАН РК У.Б. Баймуратов; докт. филос. н., проф., академик НАН РК Г.Е. Есим; докт. фил. Н., проф., академик НАН РК С.С. Кирабаев; докт. экон. Н., проф., академик НАН РК А.К. Кошанов; докт. экон. Н., проф., академик НАН РК К.Н. Нарибаев (заместитель главного редактора); докт. филос. н., проф., академик НАН РК А.Н. Нысанбаев; докт. юр. Н., проф., академик НАН РК С.Н. Саби-кенов; докт. юр. Н., проф., академик НАН РК М.К. Сулейменов; докт. экон. Н., проф., академик НАН РК С.С. Сатубалдин; докт. ист. н., проф., академик НАН РК Х.М. Абжанов; докт. ист. н., проф., чл.-корр. НАН РК М.Х. Абусеитова; докт. ист. Н., проф., академик НАН РК Б.А. Бай-танаев; докт. фил. н., проф., чл.-корр. НАН РК Б.А. Жакып; докт. фиолол. н., проф., академик НАН РК У.К. Калижанов; докт. фил. н., проф., академик НАН РК Д. Камзабекулы; докт. ист. н., проф., академик НАН РК Д.П. Кожамжарова; докт. ист. Н., проф., академик НАН РК М.К. Кой-гельдиев; докт. филол. н., проф., чл.-корр. НАН РК Ш. Курманбайулы; докт. ист. Н., проф., чл.-корр. НАН РК Ж.К. Таймаганбетов; докт. социол. н., проф., чл.-корр. НАН РК З.К. Шаукенова; д. филол. н., проф., чл.-корр. НАН РК А. Дербисали; доктор политических наук, проф., Бижанов А.К.; доктор ист. наук, проф., Кабульдинов 3.Е.; доктор филол. н., проф., член-корр. НАН РК Қажыбек Е.3.

$$
\text { Р е дакци онны й со в е т }
$$

академик НАН Республики Молдова Г. Белостечник (Молдова); академик НАН Азербайджанской Республики Н. Велиханлы (Азербайджан); академик НАН Республики Таджикистан Т.Н. Назаров (Таджикистан); академик НАН Республики Молдова А. Рошка (Молдова); академик НАН Республики Молдова Г. Руснак (Молдова); чл.-корр. НАН Азербайджанской Республики Ш. Мурадов (Азербайджан), член-корр. НАН Азербайджанской Республики 3.Сафарова (Азербайджан); д. э. н., проф. В.Н. Василенко (Украина); д.ю.н., проф. В.А. Устименко (Украина)

Известия Национальной академии наук Республики Казахстан. Серия общественных и гумани-тарных наук.

ISSN 2224-5294

Собственник: РОО «Национальная академия наук Республики Казахстан» (г. Алматы)

Свидетельство о постановке на учет периодического печатного издания в Комитете информации и архивов Министерства культуры и информации Республики Казахстан № 10894-Ж, выданное 30.04.2010 г.

Периодичность 6 раз в год

Тираж: 500 экземпляров

Адрес редакции: 050010, г. Алматы, ул. Шевченко, 28; ком. 219, 220; тел. 272-13-19, 272-13-18

http://soc-human.kz/index.php/en/arhiv 
Chief Editor

Honorary member of NAS RK

Balykbayev T.O

Editorial board:

Doctor of economics, prof, academician of NAS RK Baimuratov U.B.; doctor of philosophy, prof, academician of NAS RK Esim G.E.; doctor of philology, prof, academician of NAS RK Kirabayev S.S.; doctor of economics, prof, academician of NAS RK Koshanov A.K.; doctor of economics, prof, academician of NAS RK Naribayev K.N. (deputy editor-in-chief); doctor of philosophy, prof, academician of NAS RK Nyssanbayev A.N.; doctor of law, prof, academician of NAS RK Sabikenov S.N.; doctor of law, prof, academician of NAS RK Suleymenov M.K.; doctor of economy, prof, academician of NAS RK Satybaldin S.S.; doctor of history, prof, academician of NAS RK Abzhanov H.M; doctor of history, prof, corresponding member of NAS RK Abuseitova M.H.; doctor of history, prof, academician of NAS RK Baitanaev B.A.; doctor of philology, prof, corresponding member of NAS RK Zhakyp B.A.; doctor of philology, prof, academician of NAS RK Kalizhanov U.K.; doctor of philology, prof, academician of NAS RK Hamzabekuly D.; doctor of history, prof, academician of NAS RK Kozhamzharova D.P.; doctor of history, prof, academician of NAS RK Koigeldiev M.K.; doctor of philology, prof, corresponding member of NAS RK Kurmanbaiuly Sh.; doctor of history, prof, academician of NAS RK Taimaganbetov J.K.; doctor of sociology, prof, corresponding member of NAS RK Shaukenova Z.K.; doctor of philology, prof, corresponding member of NAS RK Derbisali A.; doctor of political science, prof Bizhanov A.K; doctor of History, prof Kabuldinov Z.E.; doctor of philology, prof, corresponding member of NAS RK Kazhybek E.Z.

\section{Editorial staff:}

Academician NAS Republic of Moldova Belostechnik.G (Moldova); Academician NAS Republic of Azerbaijan Velikhanli N. (Azerbaijan); Academician NAS Republic of Tajikistan Nazarov T.N. (Tajikistan); Academician NAS Republic of Moldova Roshka A. (Moldova) Academician NAS Republic of Moldova Rusnak G. (Moldova); Corresponding member of the NAS Republic of Azerbaijan Muradov Sh. (Azerbaijan); Corresponding member of the NAS Republic of Azerbaijan Safarova Z. (Azerbaijan); Associate professor of Economics Vasilenko V.N. (Ukraine), Associate professor of Law Ustimenko V.A. (Ukraine)

News of the National Academy of Sciences of the Republic of Kazakhstan. Series of Social and Humanities. ISSN 2224-5294

Owner: RPA "National Academy of Sciences of the Republic of Kazakhstan" (Almaty)

The certificate of registration of a periodic printed publication in the Committee of information and archives of the Ministry of culture and information of the Republic of Kazakhstan N 10894-Ж, issued 30.04.2010

Periodicity: 6 times a year

Circulation: 500 copies

Editorial address: 28, Shevchenko str., of. 219, 220, Almaty, 050010, tel. 272-13-19, 272-13-18

http://soc-human.kz/index.php/en/arhiv

(C) National Academy of Sciences of the Republic of Kazakhstan, 2020

Address of printing house: «NurNaz GRACE», 103, Ryskulov str, Almaty. 
N E W S

OF THE NATIONAL ACADEMY OF SCIENCES OF THE REPUBLIC OF KAZAKHSTAN

SERIES OF SOCIAL AND HUMAN SCIENCES

ISSN 2224-5294

https://doi.org/10.32014/2020.2224-5294.33

Volume 2, Number 330 (2020), 25 - 30

UDC: 338.48

\author{
A.E. Zheldibayev ${ }^{1}$, E.N. Nessipbekov ${ }^{1}$, \\ A.K. Belgibayev ${ }^{1}$, Zh.Zh. Belgibayeva ${ }^{2}$, G.N. Appakova ${ }^{3}$ \\ ${ }^{1}$ Almaty Technological University, Almaty, Kazakhstan; \\ ${ }^{2}$ Kazakh national agrarian University, Almaty, Kazakhstan; \\ ${ }^{3}$ Narxoz University, Almaty, Kazakhstan. \\ E-mail: zheldibaev.asan@mail.ru; nesipbekov@mail.ru; Belgibayev@mail.ru; Zhanat58@mail.ru
}

\title{
FACTORS AND PREREQUISITES FOR THE DEVELOPMENT OF HEALTH TOURISM IN KAZAKHSTAN
}

\begin{abstract}
This article discusses the problems and prospects for the development of health tourism in Kazakhstan.

The following methods were used in research: scientific abstraction, statistics-economical, analysis and synthesis.

While doing scientific research, the following results have been obtained: firstly, the necessity and possibilities of developing health-promoting types of tourism have been justified; secondly, an analysis of the availability and effectiveness of sanatorium-resort organizations has been carried out; thirdly, the prospects for the development of health tourism in Kazakhstan were justified.
\end{abstract}

Keywords: tourism, health, treatment, recreation, service, prevention, organization.

In recent years, in Kazakhstan, there is a growing demand for health-improving services. This is due to the fact that the population began to take more care of their health and appearance, has free more time and money, has information about sanatorium-resort organizations not only in their own country, but also abroad.

Health tourism involves moving people to an area with favorable climatic resources for treatment, rehabilitation programs and preventive actions to maintain vitality.

In a planned economy, in Kazakhstan, the development of health tourism was given special value. So, during that period sanatoriums, preventive clinics, rehabilitation centers, and rest homes were built, in which, using natural curative factors and in combination with rational nutrition, conducting healthimproving procedures, the population could receive a certain range of sanatorium-resort services, improve health and rest.

It should be noted that health tourism is based on balneology, which studies natural curative factors and their effects on the human body to heal from ailments, preventative treatment, medical rehabilitation, health maintenance, and recovery.

In Soviet times, the state funded R\&D in the field of balneology, issued vouchers to workers. The heads of the sanatorium organizations were engaged in the reception, accommodation of people in need of treatment, and the provision of medical and health procedures.

With the transition to the market economy, sanatorium-resort organizations had to radically change the principles and approaches to management, engage in marketing research, learn to position and inform consumers about the uniqueness, quality and accessibility of the services they offer.

Health and medical tourism is distinct by specific features that should be considered when organizing curative tours. To obtain the desired health-improving effect, it is necessary to undergo a treatment, which affects the length of stay in a particular area. Moreover, for conducting health-improving medical procedures, it is recommended to create a certain infrastructure, equip it with advanced medical facilities, pay great attention to staff qualification, and organize balanced nutrition.

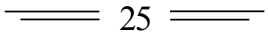


Sanatorium-resort organizations are faced with increased requirements in treatment and nutrition. All this together affects the pricing policy and the cost of offered services. Depending on their financial capabilities, lifestyle, consumers choose one or another sanatorium-resort organization.

In the conditions of increasing competition, sanatorium-resort organizations seek to create a comfortable atmosphere in the premises, develop wellness programs, cover various segments. Along with older people in need of treatment, young people come to resorts to relieve stress and receive popular spa and wellness treatments. The contingent of vacationers and people taking wellness procedures has changed significantly.

Sanatoria and resorts in Kazakhstan, in due regard of the current trend, have significantly expanded the range of services, installed modern medical equipment, offer balneological procedures, mud therapy, therapeutic showers, mineral, turpentine and antler baths, massage, physiotherapy, drinking mineral water, acupuncture, salt mine, phytobar, saunas, laboratory tests, and dietetic nutrition by local organic food. For this reason, the number of vacationers and those treated in local sanatorium-resort organizations is increasing.

Table 1 - The number of sanatorium-resort organizations in Kazakhstan in 2014-2018

\begin{tabular}{|l|c|c|c|c|c|}
\hline Types of sanatorium-resort organizations & 2014 & 2015 & 2016 & 2017 & 2018 \\
\hline Sanatoria & 66 & 62 & 66 & 65 & 73 \\
\hline Specialized sanatoria & 28 & 33 & 33 & 34 & 24 \\
\hline Preventative clinics & 17 & 14 & 14 & 12 & 11 \\
\hline Rehabilitations centers & 17 & 15 & 16 & 12 & 18 \\
\hline Other organizations & 24 & 30 & 25 & 21 & 19 \\
\hline Total & 152 & 154 & 154 & 144 & 145 \\
\hline Note: based on the source $[1, p .37,38]$ & \multicolumn{5}{|l}{} \\
\hline
\end{tabular}

Sanatorium-resort organizations are located on the whole territory of Kazakhstan and are characterized by specific services, depending on the profile of the disease. So, in the south of the country is located the famous "Sary Agash" balneological treatment and rehabilitation complex, which has its mineral well and offers not only a wide range of wellness programs, but also makes it possible to combine treatment with a good rest. The Borovoye sanatorium complex in the northern part of the country is located in a picturesque place at the foot of the magnificent mountains on the shores of the lake. Here you can cure and carry out a rehabilitation program from diseases of cardiovascular, digestive organs, blood circulation, locomotor system, respiratory system, gynecological and urological diseases. The unique nature of East Kazakhstan is of interest not only to Kazakhstanis, but also to foreigners. On the Alakol lake, skin diseases, allergies are successfully treated, strength is restored and, according to vacationers, health and well-being are improved. In the Soviet period, cosmonauts underwent rehabilitation here. In addition to Alakol, in summer, Kazakhstani people and guests from abroad can relax on the lakes of Balkhash, Shalkar, Zaysan, Markakol and the Caspian Sea. In our country, the demand for pantotherapy, bee treatment, herbal treatment, koumiss treatment, saumal treatment or cure with fresh mare's milk has increased.

According to table 1, it is clear that in 2018 in Kazakhstan, the number of sanatorium organizations amounted to 145 units, including 73 sanatoria, 24 specialized sanatoria, 11 preventative clinics, 18 rehabilitation centers, 19 other sanatorium organizations.

Table 2 - Sanatorium-resort organizations of Kazakhstan by a form of property in 2018 (units)

\begin{tabular}{|c|c|c|c|c|}
\hline \multirow{2}{*}{$\begin{array}{c}\text { Types of sanatorium-resort } \\
\text { organizations }\end{array}$} & \multirow[t]{2}{*}{ Total } & \multicolumn{3}{|c|}{ Including } \\
\hline & & $\begin{array}{c}\text { State Recreation } \\
\text { Organisations }\end{array}$ & $\begin{array}{c}\text { Private Recreation } \\
\text { Organisations }\end{array}$ & Foreign property \\
\hline Sanatoria & 73 & 6 & 65 & 2 \\
\hline Specialized sanatoria & 24 & 23 & 1 & - \\
\hline Preventative clinics & 11 & 1 & 8 & 2 \\
\hline Rehabilitations centers & 18 & 12 & 6 & - \\
\hline Other organizations & 19 & 8 & 11 & - \\
\hline
\end{tabular}


Compared to 2014, the following changes are noticeable: the total number of sanatorium-resort organizations decreased by 7 units, including the number of specialized sanatoria by 4 units, preventative clinics by 6 units, and other sanatorium organizations by 5 units respectively. The number of sanatoria during this period increased by 7 units and rehabilitation centers - by 1 unit.

The data in table 2 show that $89.04 \%$ of sanatoria; $4.16 \%$ of specialized sanatoria; $72.73 \%$ of preventative clinics; $33.33 \%$ of rehabilitation centers and $57.89 \%$ of other organizations are privately owned.

In state ownership, the number of sanatoria amounted to 6 units, specialized sanatoria -23 units, preventative clinic -1 unit, rehabilitation centers - 12 units and other sanatorium-resort organizations 8 units. There are 2 sanatoria and 2 preventative clinics which are foreign property.

Table 3 - Key performance indicators of sanatorium organizations of Kazakhstan in 2018

\begin{tabular}{|l|c|c|c|c|}
\hline $\begin{array}{c}\text { Types of sanatorium-resort } \\
\text { organizations }\end{array}$ & Number of units & $\begin{array}{c}\text { Number of beds } \\
\text { (places), units }\end{array}$ & $\begin{array}{c}\text { Bed days spent, } \\
\text { bed day }\end{array}$ & $\begin{array}{c}\text { The number of treated } \\
\text { (vacationers), people }\end{array}$ \\
\hline Sanatoria & 73 & 10033 & 1676103 & 190941 \\
\hline Specialized sanatoria & 24 & 2775 & 828444 & 14810 \\
\hline Preventative clinics & 11 & 1542 & 210568 & 24607 \\
\hline Rehabilitations centers & 18 & 2523 & 573314 & 45694 \\
\hline Other organizations & 19 & 3355 & 346979 & 23039 \\
\hline Total & 145 & 20228 & 3635408 & 299091 \\
\hline Note: based on the source $[1, p .37,38,39,40]$ & & \\
\hline
\end{tabular}

The total number of places in 2018 was 20,228 units, including 10,033 places in sanatoria; 2775 places - in specialized sanatoria; 1542 places - in preventative clinics; 2523 places - in rehabilitation centers and 3355 places in other organizations.

In $2018,1,676,103$ bed days were spent in sanatoria, 828,444 bed days in specialized sanatoria, 210,568 bed days in preventative clinics, 573,314 bed days in rehabilitation centers, and 346,979 bed days in other sanatorium-resort organizations. The total number of bed-days for all types of sanatorium-resort organizations amounted to 3635408 bed-days.

In 2018 , the total number of vacationers reached 2,99091 people. If we consider the types of organization, then $63.84 \%$ of the total number of vacationers underwent treatment in sanatoria; $4.95 \%-$ in specialized sanatoria; $8.23 \%$ - in preventative clinics; $15.28 \%$ - in rehabilitation centers; $7.70 \%$ - in other sanatorium-resort organizations.

In conclusion, it should be noted that the climatic conditions of Kazakhstan, the presence of unique healing mud, mineral springs, beaches, local sightseeing attractions, organic food products form a natural resource potential and contribute to the dynamic development of health tourism.

The development of health tourism in Kazakhstan will have a multiplier effect, which is expressed not only in replenishing the revenue side of state and local budgets, but also in creating additional jobs, increasing employment rate and quality of life, reducing mortality and increasing the life expectancy of the local population.

\section{А.Е. Желдибаев ${ }^{1}$, Е.Н. Несипбеков ${ }^{1}$, А.К. Бельгибаев ${ }^{1}$, Ж.Ж. Бельгибаева ${ }^{2}$, Г.Н. Аппакова ${ }^{3}$ \\ 1 Алматы технологиялық университеті, Алматы, Қазақстан; \\ 2 Қазақ ұлттық аграрлық университеті, Алматы, Қазақстан; 3 "Нархоз" Университеті, Алматы, Қазақстан \\ ҚАЗАҚСТАНДАҒЫ ЕМДЕУ-САУЫҚТЫРУ ТУРИЗМІНІН ДАМУ ФАКТОРЛАРЫ МЕН ШАРТТАРЫ}

Аннотация. Қазақстанда соңғы жылдары емдеу-сауықтыру қызметтеріне сұраныс артып келеді. Бұл халықтың денсаулығы мен келбетіне көбірек көңіл бөле бастағаны, бос уақыты мен ақшасы бар, тек өз елінде ғана емес, сонымен қатар шетелде де санаториялық-курорттық ұйымдар туралы ақпаратқа ие екенін білдіреді. 
Денсаулық сақтау туризмі адамдарды емдеуге қолайлы климаттық ресурстары бар аймаққа көшуді, қалпына келтіру бағдарламаларын және өміршеңдікті сақтау жөніндегі алдын-алу шараларын қамтиды.

Жоспарлы экономикада Қазақстандағы сауықтыру туризмін дамытуға ерекше мән берілген. Ол кезеңде санаторий, профилакторий, реабилитациялық орталықтар мен демалыс үйлері салынған, онда табиғи емдік факторларды пайдалана отырып, тиімді тамақтанумен, емдеу-сауықтыру процедураларын алумен қатар, тұрғындар кешенді санаториялық-курорттық қызметтерді ала отырып, денсаулықтарын жақсартқан және демалған.

Айта кету керек, емдеу-сауықтыру туризмі табиғи емдік факторларды және олардың адам ағзасына ауруларды сауықтыру, аурулардың алдын алу, медициналық оңалту, денсаулықты сақтау және қалпына келтіру үшін әсер ететін курортология ғылымына негізделген.

Кеңестік кезеңде мемлекет курортология саласындағы ғылыми зерттеулерді қаржыландырған, еңбекшілерге жолдама берген. Санаториялық-курорттық ұйымдардың басшылары емдеуді мұқтаж еткен адамдарды қабылдаумен, орналастырумен, емдік-сауықтыру процедураларын жасаумен айналасқан.

Нарыққа көшуіне байланысты санаториялық-курорттық ұйымдарға басқару принциптері және тәсілдерін түбегейлі өзгертуге, маркетингтік зерттеулермен айналасуға, тұтынушыларға ұсынатын қызметтердің бірегейлігі, сапасы және қол жетімділігі туралы ақпарат беруге тура келді.

Емдеу-сауықтыру туризмі өзіне тән арнайы ерекшеліктерімен сипатталады, оларды емдік турларды ұйымдастыру кезінде ескеру қажет. Қажетті емдік әсерге қол жеткізу үшін, белгілі бір аймақта болу ұзақтығымен байланысты емдеу курсынан өту керек. Сонымен қатар, сауықтыру медициналық процедураларды өткізу үшін белгілі бір инфрақұрылымды құру, озық медициналық құрал-жабдықтармен жарақтандыру, персоналдың біліктілігін арттыруына көп қөңіл аудару, тиімді тамақтануды ұйымдастыру ұсынылады.

Санаториялық-курорттық ұйымдарға емдеу, тамақтану жөнінен жоғары талап қойылады. Мұның барлығы баға саясатына және ұсынылатын қызметтердің құнына әсер етеді. Тұтынушылар санаториялықкурорттық мекемені өзінің қаржылық мүмкіндіктеріне, салауатты өмір салтына байланысты таңдайды.

Сөз соңында айта кету керек, Қазақстанның табиғи-климаттық жағдайлары, бірегей емдік балшықтың, минералды көздердің, жағажайлардың, жергілікті көрікті жерлердің, экологиялық таза азық-түлік өнімдердің бар болуы табиғи-ресурстық әлеуетті қалыптастырады және сауықтыру туризмінің қарқынды дамуына ықпалын тигізеді.

Қазақстанда сауықтыру туризмінің дамуы мемлекеттік және жергілікті бюджеттердің кіріс бөлігін толықтыруға ғана емес, қосымша жұмыс орындарын құруға, жұмыспен қамту және өмір сүру сапасын жоғарылатуға, өлім-жітімнің төмендеуіне, сондай-ақ жергілікті тұрғындардың өмір сүру ұзақтығын арттыруға да әсерін тігізеді.

Зерттеу жүргізу кезінде келесі әдістер пайдаланылған: ғылыми абстракция, статистикалық- экономикалық әдіс, анализ және синтез.

Ғылыми зерттеулерді орындау кезінде, келесі нәтижелер алынған: біріншіден, туризмнің сауықтыру түрін дамыту қажеттігі және мүмкіндігі дәлелделген; екіншіден, санаториялық-курорттық ұйымдардың бар болуына және жұмыс істеу тиімділігіне талдау жүргізілген; үшіншіден, Қазақстандағы сауықтыру туризмінің даму перспективалары негізделген.

Кілт сөздер: туризм, денсаулық, емдеу, демалу, қызмет, профилактика, ұйым.

\section{А.Е. Желдибаев ${ }^{1}$, Е.Н. Несипбеков ${ }^{1}$, А.К. Бельгибаев ${ }^{1}$, Ж.Ж.Бельгибаева ${ }^{2}$, Г.Н. Аппакова ${ }^{3}$ \\ ${ }^{1}$ Алматинский технологический университет, Алматы, Казахстан; \\ ${ }^{2}$ Казахский национальный аграрный университет, Алматы, Казахстан; \\ ${ }^{3}$ Университет «Нархоз», Алматы, Казахстан \\ ФАКТОРЫ И ПРЕДПОСЫЛКИ РАЗВИТИЯ ЛЕЧЕБНО-ОЗДОРОВИТЕЛЬНОГО ТУРИЗМА В КАЗАХСТАНЕ}

Аннотация. За последние годы в Казахстане растет спрос на лечебно- оздоровительные услуги. Это объясняется тем, что население стало проявлять больше заботы о своем самочувствии и внешнем виде, имеет свободное время и денежные средства, обладает информацией о санаторно- курортных организациях не только в своей стране, но и за рубежом.

Оздоровительный туризм предусматривает перемещение людей в местность, обладающую благоприятными природно-климатическими ресурсами для лечения, прохождения реабилитационной программы и проведения профилактических мер для поддержания жизненных сил. 
При плановой экономике развитию оздоровительного туризма в Казахстане придавалось особое значение. Так, в тот период были построены санатории, профилактории, реабилитационные центры, дома отдыха, в которых с использованием природных целебных факторов и в сочетании с рациональным питанием, проведением лечебно- оздоровительных процедур население могло получать определённый комплекс санаторно-курортных услуг, поправлять здоровье и отдыхать.

Следует отметить, что лечебно-оздоровительный туризм базируется на науке курортологии, изучающей природные лечебные факторы и их воздействие на организм человека с целью исцеления от недугов, профилактики заболеваний, медицинской реабилитации, сохранения и восстановления здоровья.

В советский период государство финансировало научные исследования в области курортологии, выдавало путевки трудящимся. Руководители санаторно-курортных организаций занимались приемом, размещением лиц, нуждающихся в лечении, оказанием лечебно- оздоровительных процедур.

С переходом к рынку санаторно-курортным организациям пришлось коренным образом поменять принципы и подходы к управлению, заниматься маркетинговыми исследованиями, научиться позиционировать и информировать потребителей об уникальности, качестве и доступности предлагаемых ими услуг.

Лечебно-оздоровительный туризм отличается специфическими особенностями, которые необходимо учесть при организации лечебных туров. Для получения желаемого оздоровительного эффекта необходимо пройти курс лечения, что влияет на продолжительность пребывания в той или иной местности. Более того, для проведения оздоровительных медицинских процедур рекомендуется создать определенную инфраструктуру, оснастить передовым медицинским оборудованием, уделить огромное внимание повышению квалификации персонала, организовать рациональное питание.

К санаторно-курортным организациям предъявляются повышенные требования в области лечения, питания. Все это в совокупности сказывается на ценовой политике и стоимости предлагаемых услуг. Потребители в зависимости от своих финансовых возможностей, образа жизни выбирают то или иное санаторно-курортное учреждение.

В заключение необходимо отметить, что природно-климатические условия Казахстана, наличие уникальных лечебных грязей, минеральных источников, пляжей, местных достопримечательностей, экологических чистых продуктов питания формируют природно-ресурсный потенциал и способствуют динамичному развитию оздоровительного вида туризма.

Развитие оздоровительного туризма в Казахстане даст мультипликативный эффект, который выражается не только в пополнении доходной части государственного и местного бюджетов, но и в создании дополнительных рабочих мест, повышении уровня занятости и качества жизни, снижении смертности и увеличении продолжительности жизни местного населения.

При проведении исследований использованы следующие методы: научной абстракции, статистикоэкономический, анализа и синтеза.

При выполнении научных исследований получены следующие результаты: во-первых, обоснована необходимость и возможности развития оздоровительного вида туризма; во-вторых, проведен анализ наличия и эффективности функционирования санаторно-курортных организаций; в-третьих, обоснованы перспективы развития оздоровительного туризма в Казахстане.

Ключевые слова: туризм, здоровье, лечение, отдых, услуга, профилактика, организация.

Information about the authors:

Asan Zheldibayev - Candidate of Science in Economics, Associate Professor, Department of Tourism and Service, Almaty Technological University, https://orcid.org/0000-0002-2304-8889;

Erkin Nesipbekov - PhD, head of the Department of Tourism and Service, Almaty Technological University, https://orcid.org/0000-0003-4766-5555;

Almaz Belgibayev - Candidate of Science in Economics, Associate Professor, Department of Tourism and Service, Almaty Technological University;

Zhanat Belgibayeva - Doctor of Science in Economics, Professor, Department of Management and Agribusiness Organization, Kazakh National Agrarian University, https://orcid.org/0000-0003-3506-1770;

Gulmira Appakova - PhD, Associate Professor, Narxoz University

\section{REFERENCES}

[1] Turizm Kazahstana. Statisticheskij sbornik. Nur-Sultan, 2019. S. 37,38,39,40.

[2] Vetitnev A.M., Torgasheva A.A. Harakteristika osnovnyh pokazatelej sostoyaniya lechebno-ozdorovitel'nogo turizma v Rossijskoj Federacii // Nauchnyj zhurnal NIU ITMO. Seriya «Ekonomika i ekologicheskij menedzhment». 2014. № 4. S.86-96.

[3] Babkin A.V. Special'nye vidy turizma. Uchebnoe posobie. Rostov-na-Donu, 2008. S. 40-55.

[4] Abenova E.A. Perspektivy razvitiya lechebno-ozdorovitel'nogo turizma v Kazahstane // Azimut nauchnyh issledovanij: ekonomika i upravlenie, 2015. № 1 (10). S.7-10. 
[5] Sikorskaya V.A. Razvitie lechebno- ozdorovitel'nogo turizma v sovremennyh usloviyah // Vestnik RMAT, 2014 . №3. S. 34-40.

[6] Vojnova YA.A., CHuvatkina O.P. Prognozirovanie razvitiya lechebno-ozdorovitel'nogo turizma // Rossijskoe predprinimatel'stvo. 2007. № 11. S. 107-111.

[7] Vetitnev A.M., Vojnova YA.A. Organizaciya sanatorno-kurortnoj deyatel'nosti: uchebnoe posobie / A.M. Vetitnev, YA.A. Vojnova. M.: Federal'noe agentstvo po turizmu, 2014. 272 s.

[8] Orlova V.S., SHCHerbakova A.A. Perspektivy razvitiya lechebno-ozdorovitel'nogo turizma v regione // Problemy razvitiya territorii, 2014. - № 4 (72). S. 34-47.

[9] Tleuberdinova A.T., SHaekina ZH.M., Salauatova D.M., Torzhanova D.A. Znachenie razvitiya vnutrennego turizma dlya ekonomiki strany // Vestnik Karagandinskogo universiteta. Seriya «Ekonomika». 2017. № 3(87). S.11-20.

[10] Korablev V.A. Perspektivy razvitiya turizma v Kazahstane //Vestnik universiteta «Turan». 2018. № 4(80). S. 147-150.

[11]Kalenova S.A. Mirovoj opyt razvitiya medicinskogo turizma // Vestnik universiteta «Turan». 2018. № 4 (80). S.142-146.

[12] Alikulova A.SH. Sanatorno-kurortnyj kompleks Kazahstana: osobennosti i perspektivy razvitiya // Vestnik KazNU. Seriya ekonomicheskaya. 2011. №6(88) S. 70-73.

[13] Makenova G.U., Daurenbekova A.N., Tuleubaeva M.K. Rynok mezhdunarodnogo turizma i ego rol' v razvitii nacional'noj ekonomiki //Izvestiya Nacional'noj akademii nauk Respubliki Kazahstan. Seriya obshchestvennyh i gumanitarnyh nauk. 2019. № 5(327). S.186-198. ISSN 2224-5294 https://doi.org/10.32014/2019.2224-5294.187

[14] Doshan A.S., Rej I.YU., Sayabaev K.M. Perspektivy razvitiya sel'skogo zelenogo turizma // Doklady NAN RK, 2018. №3. S. 55-60.

[15] Umahanova A.SH., Amirova M.M. Programma strategicheskogo razvitiya lechebno- ozdorovitel'nogo turizma i ee realizaciya v respublike Dagestan// Fundamental'nye issledovaniya. 2017. № 1. S. 219-222.

[16] Desyatnichenko D. YU., Desyatnichenko O. YU., SHmatko A.D. O proekte strategii razvitiya sanatorno-kurortnogo kompleksa Rossijskoj Federacii (analiz problemnoj situacii i celepolaganiya)//Upravlencheskoe konsul'tirovanie, 2017. № 12. S.120-129. DOI 10.22394/1726-1139-2017-12-120-129

[17] Oborin M.S., Mingaleva ZH.A. Napravleniya i tendencii razvitiya sanatorno-kurortnogo kompleksa i lechebnoozdorovitel'nogo turizma yuzhnyh regionov Rossii v nestabil'nyh social'no-ekonomicheskih usloviyah / M. S. Oborin, ZH. A. Mingaleva // Nauchnye vedomosti BelGU. Ser. Ekonomika. Informatika. 2017. №2(251), vyp.41. S. 32-37.

[18] Andropova E.M., Romanenkov A.I., Grzhebina L.M., Podkorytova E.A., Kut'in I.V. Analiz problem i perspektiv razvitiya lechebno-ozdorovitel'nogo turizma v Krymu // Servis v Rossii i za rubezhom, 2016. № 3(64). S.92-106.

[19] Dracheva E.L. Special'nye vidy turizma. Lechebnyj turizm. M: Knorus, 2010. $152 \mathrm{s.}$

[20] Kairova A.A. Statisticheskij obzor razvitiya kazahstanskogo turizma // Vestnik universiteta «Turan». 2017. № 4(76). S. 154-158. 


\title{
PUBLICATION ETHICS AND PUBLICATION MALPRACTICE IN THE JOURNALS OF THE NATIONAL ACADEMY OF SCIENCES OF THE REPUBLIC OF KAZAKHSTAN
}

For information on Ethics in publishing and Ethical guidelines for journal publication see http://www.elsevier.com/publishingethics and http://www.elsevier.com/journal-authors/ethics.

Submission of an article to the National Academy of Sciences of the Republic of Kazakhstan implies that the work described has not been published previously (except in the form of an abstract or as part of a published lecture or academic thesis or as an electronic preprint, see http://www.elsevier.com/postingpolicy), that it is not under consideration for publication elsewhere, that its publication is approved by all authors and tacitly or explicitly by the responsible authorities where the work was carried out, and that, if accepted, it will not be published elsewhere in the same form, in English or in any other language, including electronically without the written consent of the copyrightholder. In particular, translations into English of papers already published in another language are not accepted.

No other forms of scientific misconduct are allowed, such as plagiarism, falsification, fraudulent data, incorrect interpretation of other works, incorrect citations, etc. The National Academy of Sciences of the Republic of Kazakhstan follows the Code of Conduct of the Committee on Publication Ethics (COPE), and follows the COPE Flowcharts for Resolving Cases of Suspected Misconduct (http://publicationethics.org/files/u2/New_Code.pdf). To verify originality, your article may be checked by the originality detection service Cross Check http://www.elsevier.com/editors/plagdetect.

The authors are obliged to participate in peer review process and be ready to provide corrections, clarifications, retractions and apologies when needed. All authors of a paper should have significantly contributed to the research.

The reviewers should provide objective judgments and should point out relevant published works which are not yet cited. Reviewed articles should be treated confidentially. The reviewers will be chosen in such a way that there is no conflict of interests with respect to the research, the authors and/or the research funders.

The editors have complete responsibility and authority to reject or accept a paper, and they will only accept a paper when reasonably certain. They will preserve anonymity of reviewers and promote publication of corrections, clarifications, retractions and apologies when needed. The acceptance of a paper automatically implies the copyright transfer to the National Academy of sciences of the Republic of Kazakhstan.

The Editorial Board of the National Academy of sciences of the Republic of Kazakhstan will monitor and safeguard publishing ethics.

Правила оформления статьи для публикации в журнале смотреть на сайте:

\author{
www:nauka-nanrk.kz \\ http://soc-human.kz/index.php/en/arhiv \\ Редакторы: М. С. Ахметова, Г. Б. Халидуллаева, Д. С. Аленов \\ Верстка на компьютере А.М. Кульгинбаевой \\ Подписано в печать 19.03..2020 \\ Формат 60x881/8. Бумага офсетная. Печать - ризограф. \\ 14 п.л. Тираж 500. Заказ 2.
}

Национальная академия наук $Р К$

050010, Алматы, ул. Шевченко, 28, т. 272-13-18, 272-13-19 